\title{
COMPARISON OF ACCOUNTING SYSTEMS FOR MICRO LEGAL ENTITIES IN SLOVENIA AND SERBIA REFERING TO THE NEW EU ACCOUNTING DIRECTIVE
}

\author{
Tatjana Jovanović \\ Faculty of Administration, University of Ljubljana, Slovenia
}

\begin{abstract}
:
Financial accounting is traditionally oriented towards the recording of the past business events and preparing of financial statements. The informational value of accounting reports is intended for a wide range of users; the owners, financiers, employees, etc. In the domain of small and mediumsized enterprises and entrepreneurs (hereinafter SMEs) practice shows extensive use of information that financial statements can offer and adoption of accounting policies that are critical for planning opportunities, business strategy, capital management, etc. As the SMEs (especially the micro legal entities) represent the majority of economies, this paper explores the legal regulations in the field of accounting and financial reporting for micro companies in Slovenia and Serbia and comparative analysis of the similarities and differences of the regulatory framework and the contents of this regulation, with special emphasis on the complexity of the annual financial reporting in light of the New Accounting Directive (2013/34 / EU).
\end{abstract}

\author{
Key words: \\ accounting system, \\ accounting, \\ SME, \\ micro entity, \\ financial report.
}

\section{INTRODUCTION}

Financial accounting consists of planning, bookkeeping, analyzing and controlling, from which financial reporting is derived. Considering relevant characteristics of the micro entities, the paper focuses on the bookkeeping part of the accounting system and external financial reporting ${ }^{1}$. Bookkeeping is directed to the overall presentation of entity operations - to display the respective assets and liabilities as well as all revenues and expenditures in the observed period. The main purpose of the overall presentation is to prepare certain data for the external but also for the internal interested parties (Turk at al., 2004, Kimmel et al., 2004, Weetman, 2003).

The small and medium-sized enterprises are the backbone of the European economy, and they are the main contributors to the creation of employment in the EU. Generally, SMEs represent the largest part of the economies all over the world, so the phenomenon is common in Slovenia, in Serbia, but also in the EU. Data show that in the EU there are around 23 million SMEs, what represents $99 \%$ of all businesses. Despite the enormous meaning of the small and medium enterprises and entrepreneurs (hereinafter SMEs) for the economies, EU SMEs still have lower productivity and grow more slowly than their counterparts in the United States. In the US, surviving firms on average increase their employment by $60 \%$ by their seventh year, while employment gains among surviving firms in Europe are in the order of $10 \%$ to $20 \%$. The importance of micro entities can be expressed by reported data for 2013. Across the EU28 19.969.338 $(92,4 \%)$ micro entities in the non - financial business sector employed 38.629 .012 employees $(29,1 \%)$ and generated 1.362.336 million EUR $(21,6 \%)$ in value added (European Commission, 2011, European Commission, 2014).

1 There are some authors that divide external financial reporting and financial accounting. The financial accounting studies in monetary unist expressed economic categories (data), while external financial reporting forwards this data to the groups outside the
The paper explores the legal regulations in the field of accounting and financial reporting for micro companies in Slovenia and Serbia. Using the methodology of comparative analysis it reveals the similarities and differences of the regulatory framework and the contents of this regulation, with special emphasis on the complexity of the annual financial reporting aforementioned group of economic operators. Comparing the system of EU member (Slovenia) and non-EU member (Serbia) it relies on the new accounting EU directive (2013/34 / EU), which is the product of the commitment to the European Commission program "smart legislation of the European Union" and sets the model of financial reporting for SMEs.

\section{ACCOUNTING SYSTEMS FOR MICRO COMPANIES}

The definition of SMEs is not unique. Criteria for defining the size of the company vary widely between countries and change frequently. It depends on the degree of development and the overall scale of economic activity. A firm with turnover of less than 10 million EUR categorized as 'small' in the European Union, for example, but in many developing countries would be included in the large units. Based on the recommendations of the European Commission and the World Bank SMEs are defined based on the criteria of the number of employees, annual revenue and assets in the balance sheet. According to the World Bank, micro entities are the one with less than 10 employees and asset less than 100.000 USD, while EU defines it as the entities with less than 10 employees and less than 2 million EUR balance sheet total or 2 million EUR of turnover (International Monetary Fund, 2007).

Apart from formal, purely statistical, differentiation of the group, only a few rules regulate in favor of SMEs, and in particular the administrative burden and costs of compliance with these disproportionate to the large companies. On the EU level 
this adjustments are more often. In June 2008 European Commission adapted Small Business Act for Europe that reflects the Commission's political will to recognize the central role of SMEs in the EU economy and for the first time puts into place a comprehensive SME policy framework for the EU and its Member States. In the accounting area, even Fourth Council Directive from 1978 mentions micro-entities as the ones that member states may provide for exemptions from certain obligations in case balance sheet total does not exceeds 350.000 euro, net turnover in under 700.000 euro and the average number of employees during the financial year does not exceeds 10 .

SMEs operate in different organizational forms. In general, there are three possible organizational forms: sole proprietorship, partnership, and corporation ${ }^{2}$. Businesses operating in any of organizational form can be classified in SMEs or even micro entities in case of fulfillment the Directive limits. Defining the micro entities, it is important to mention that the Accounting Directives refer only to the limited liability companies while unlimited liability companies and self-entrepreneurs are not the subject of the EU accounting regulation. Micro entity is the term from the accounting directive (Fourth Council Directive, 1978).

Legal framework for accounting field worldwide is International Financial Accounting Standards (IFRS). The term is used as the expression for accounting tool (standard) all over the world or as the concrete International Accounting Standards (IAS) prepared and published by the International Accounting Standards Board. On the contrary, there are several national accounting standards prepared by the national institutions. The most popular national accounting standards are Generally Accepted Accounting Principles (GAAP). At the EU level the legal framework is based on the Fourth Council Directive from 1978 and the Seventh Council Directive of 13th June 1983 on consolidated accounts. Besides those two basic regulations ${ }^{3}$, it is important to highlight Transparency Directive, Prospectus Directive and Equivalence mechanism established by the EU to determine whether third countries' accounting standards are equivalent to EU ones (Novak, 2007).

Literature review shows that there are several accounting system at the EU level, as follows (Laptes and Popa, 2012):

- the normal accounting system that ensures the provision of information depending on the users' needs with the help of the annual financial statements presented in a developed form;

- the simplified accounting system that is characterized by the presentation of financial information with the help of the financial statements drawn up in a simplified form;

- the super simplified accounting system that involves the organization of the accounting of receipts and payments flows, also known as cash accounting.

In the time when Accounting Directives were developed the prevailing idea was that SMEs are not fundamentally different

2 Business owned by one person is a sole proprietorship, but when there is more than one person in ownership, we name it partnership. A business organized as a separate legal entity owned by stockholders is a corporation. Sole proprietorship is simple to set up and offers the owner a certain control over the business. Joining the forces with other individuals can lead to partnership. The main reason for choosing the partnership is lack of economic resources to initiate or expand the business or to bring unique skills or resources. Finally one can choose the corporation form, in which an investor receives shares of stock to indicate your ownership claim. The advantages of organizing the corporation than partnership are in possibility of easiest selling the share (Kimme et al., 2004)

3 Directive shall be binding, as to the result to be achieved, upon each Member State to which it is addressed, but shall leave to the national authorities the choice of form and methods (Treaty establishing the European Community, 249. Art.) from large companies and should follow similar reporting requirements. This view has subsequently changed with acknowledgment of distinct needs of the SME group - laid down as the "think small first" principle. It is important to consider which requirements should be removed or replaced in order to simplify financial reporting for micro-entities. As a consequence of this fact, a large number of Member States have developed their own national accounting legislation (local GAAP) for those enterprises. This has resulted in a diversified accounting legislation for small enterprises such as sole proprietorships and partnerships with unlimited liability (European Commission, 2008).

On the other hand, in July 2009 the International Accounting Standards Board (IASB) issued International Financial Reporting Standard for Small and Medium-sized Entities (IFRS for SMEs) (IASC Foundation, 2009a). This standards were consistent with the intent to address the need for international comparability in the financial reporting of SMEs and are seen as a response to international demand in both developed and emerging economies for a simpler version of International Financial Reporting Standards (IFRSs) (Jermakowicz and Epstein, 2010). The need and potential usefulness of IFRS for SMEs can vary across countries because of the countries characteristics such as the stage of economic development, development of the accounting profession, size of the business and importance of public versus private companies differ, the need and potential usefulness of IFRS for SMEs can vary across countries (Albu et al., 2013). Despite the economic importance of SMEs, there is a limited understanding of the accounting issues these entities face. SMEs do not have the same incentives for high-quality reporting as larger public companies, and the resulting lack of transparency may affect their contracts with outside parties. There were also highlighted the low level of literacy, lack of accounting education and the absence of computerized accounting systems in a SMEs environment (Roberts and Sian, 2006).

For many years European Commission was trying to find an appropriate solution for SMEs, including micro ones. The problem is that on average, a business with fewer than ten employees has to face a regulatory burden (measured per employee) that is roughly twice as high as the burden of a business with more than ten but less than twenty employees and about three times as high as the burden of businesses with more the an twenty but less than fifty employees. For bigger companies, the burden per employee is only one fifth or less of that of small enterprises. That means, that where a big enterprise spends one euro per employee to comply with a regulatory duty a medium-sized enterprise might have to spend around four EUR and a small business up to ten EUR. Finally, the specific position of micro companies is observed by the fact, that the main users of financial reports of micro entities are more likely to demand specific information (for example on recoverable amount of assets (banks) or taxable profit (tax authorities) rather than various disclosures or sophisticated accrual accounting information. At the same time, companies that have to produce essentially investor oriented accounts devote time and money to accounting techniques that use no purpose and only satisfy legal requirements. They often need help from external accountants to prepare these accounts as these techniques are often complex and not the core competence of the managers of micro business. For the same reason the statutory accounts seldom provide useful information for managers to utilize. Furthermore, most of the additional information is not of interest to stakeholders of SME's (European Commission, 2009).

In addition, we focus on comparison of two Central and Eastern Europe (CEE) accounting systems for micro legal entities. For this group of countries there are some common observations concerning moderations of accounting systems implementing IFRS for SMEs. The regulators' interest in IASs/IFRSs was raised by the need to present the countries as modern ones, 
willing to attract foreign investors. Additionally, the countries' political will to join the European Union (EU) compelled the national regulators to ensure a high level of harmonization with the European Directives even before these countries joined the $\mathrm{EU}$, and concluded with their enactment subsequently (for the ones that in the end became full members) (Albu, 2013).

\section{ACCOUNTING SYSTEM IN SLOVENIA AND SERBIA}

The comparison of two different accounting systems originating from the common EX-YU system is nowadays very interesting. Slovenia has gone through two decades of changes, mainly conditioned with EU membership. As a Member State it is obligated to follow EU aquis adjusting it to a specific national system, public administration tradition and mentality. On the other side, Serbia is going through the accession negotiations for EU membership.

In addition, we will present some common characteristics and some differences of the Slovenian and Serbian accounting system for micro entities (self-entrepreneurs excluded because of the EU Directive) in force (Table 1). Observing the first descriptive category, which actually delineates micro entities in each country, we can see that Slovenian criteria exceed criteria in Serbia for 3 to 6 times. While both have the condition, that micro entity is the one with no more than 10 employees, the turnover and net average asset in Slovenia is set on 2 million EUR, while in Serbia is 350.000 EUR for turnover and 700.000 EUR for asset. Those criteria for Serbia are harmonized with new EU Accounting Directive, while Slovenia is considering the changes of the Company Act these days.

There is also difference in those two systems as far as legislation concerning accounting issues. In Slovenia Company Act as the statutory act defines the possible legal/organizational forms of companies, the limits for the size of companies, the accounting rules for certain legal form of the organization, legal possibilities for mergers and acquisitions, etc. In Serbia this subject is left to Accounting Act. On the other hand, in both countries legislation defining micro entities refers to specific accounting legislation. In Slovenia accounting rules for micro companies are Slovenian Accounting Standards (SAS) and subsidiary use of International Accounting Standards when needed. In Serbia implementing regulation - Regulations on the method recognition, valuation, presentation and disclosure position in individual financial statements of micro and other legal entities - was adopted in 2013 related to the Accounting Act also adopted in 2013 (Official Journal 68/2013). The Accounting Act optionally enables the micro entities to use International Accounting Standards for SMEs while the implementing regulation is the short version of IAS for SMEs.
Finally, we refer to some novelties from the New Accounting Directive (2013/34/EU):

- where a Member State applies one or more of the optional exemptions for micro-undertakings, micro-undertakings should also be defined by reference to balance sheet total, net turnover and the average number of employees during the financial year;

- micro-undertakings should still be subject to any national obligation to keep records showing their business transactions and financial position;

- Member States should take into account the specific conditions and needs of their own markets when making a decision about whether or how to implement a distinct regime for micro-undertakings within the context of this Directive;

- Member States making use of the exemptions for microundertakings provided for in this Directive should be allowed to exempt micro-undertakings from a general publication requirement, provided that balance sheet information is duly filed, in accordance with national law, with at least one designated competent authority and that the information is forwarded to the business register, so that a copy should be obtainable upon application

- it may permit not to display the categories: a) prepayments and accrued income, and b) accruals and deferred income,

- exception of the obligation to draw up notes to the financial statements in accordance with Article 16;

- the exception of the obligation to prepare a management report in accordance with Chapter 5 ,

- the obligation to publish annual financial statements in accordance with Chapter 7.

\section{CONCLUSION}

The specificities of SMEs require different treatment by the economic policies as a segment of large companies. For this reason, in June 2008 the EU adopted the Small Business Act for Europe which requires that the law takes into account the interests of SMEs in the very early stages of policy-making, with a view to more humane legislation. In this context and considering enormous administrative cost of financial reporting for SMEs (especially micro entities), New Accounting Directive was improved. It should be noted that tax authorities usually have special reporting needs which differ significantly from general financial reporting. Customers may wish to know about a small company's ability to remain in business if it is a major supplier; potential suppliers may want to know about the company's policies toward paying its creditors; and external shareholders will want information on the value of their shares and the value of

\begin{tabular}{|c|c|c|}
\hline Criteria & Slovenia & Serbia \\
\hline Micro entity & $\begin{array}{l}\text { - Average number of employees } 10 ; \\
\text { - Net sales revenue } 2.000 .000 \text { EUR; } \\
\text { - Average value of asset max. } 2.000 .000 \mathrm{EU}\end{array}$ & $\begin{array}{l}\text { - Average number of employees } 10 \text {; } \\
\text { - Net sales revenue } 700.000 \text { EUR; } \\
\text { - Average value of asset max. } 350.000 \text { EUR }\end{array}$ \\
\hline Legislation defining micro entity & Company Act (ZGD-1) & Accounting act \\
\hline $\begin{array}{l}\text { Recognition, valuation, presenta- } \\
\text { tion and disclosure of financial } \\
\text { categories/statements }\end{array}$ & - Slovenian Accounting Standards (SAS) & $\begin{array}{l}\text { - International Accounting Standards for SME or } \\
\text { - Regulations on the method recognition, valu- } \\
\text { ation, presentation and disclosure position in } \\
\text { individual financial statements of micro and } \\
\text { other legal entities }\end{array}$ \\
\hline Accounting method & Double-entry bookkeeping & Double-entry bookkeeping \\
\hline Legal auditing obligation & Non & Tax Authority \\
\hline Annual Financial Report & $\begin{array}{l}\text { - Balance sheet } \\
\text { - Profit and loss account } \\
\text { - Explanation to the financial reports }\end{array}$ & $\begin{array}{l}\text { - Balance sheet } \\
\text { - Profit and loss account }\end{array}$ \\
\hline
\end{tabular}

Table 1: Accounting systems for micro entities in Slovenia and Serbia

[Source: own] 
the company, as well as the future prospects, strategy and plans of the management. This information is only partly to be gained from the statutory accounts, and it is often out-of-date by the time the accounts are published. (e.g. in the UK it takes on average 10 months before accounts are published) (European Commission, 2009)

\section{REFERENCES}

[1] Albu, C., Accounting in Central and Eastern Europe, USA, Emerald Group Publishing Limited, 2013, pp. 1-321

[2] Albu, C. N., Albu1, N., Pali-Pista, S.F., Gîrbină, M. M., Selimoglu, S.K., Kovács, D. M., Lukács, J., Mohl, G., Müllerová, L., Paseková, M., Arsoy, A. P. and Strouhal, J., "Implementation of IFRS for SMEs in Emerging Economies: Stakeholder Perceptions in the Czech Republic, Hungary, Romania and Turkey", Journal of International Financial Management \& Accounting, vol. 24, no. 2, 2013, pp. 140-175

[3] DIRECTIVE 2013/34/EU OF THE EUROPEAN PARLIAMENT AND OF THE COUNCIL of 26 June 2013, L2/19, (pristup 15.10.2014), [dostupno na http://eur-lex.europa.eu/ legal-content/EN/ALL/ELX_SESSIONID=KKYYJh4PGhvvc QRJKT27nQfkSnsty3LhQVFRhR5ffQ8nyp2KjRxd!18218989 24? uri=CELEX:32013L0034].

[4] European Commission (1978): "Fourth Council Directive based on Article 54 (3) (g) of the Treaty on the annual accounts of certain types of companies (78/660/EEC), (pristup 10.11.2014), [dostupno na http://eur-lex.europa. eu/legal-content/EN/TXT/PDF/?uri=CELEX:01978L066020120410\&from $=\mathrm{EN}$ ]

[5] European Commission (2013): "Directive 2013/34/EU (2013) of the European parliament and of the council on the annual financial statements, consolidated financial statements and related reports of certain types of undertakings, amending Directive 2006/43/EC of the European Parliament and of the Council and repealing Council Directives 78/660/EEC and 83/349/EEC", Official Journal of the European Union L $182 / 19$

[6] European commission (2008): "Final report of the expert group accounting systems for small enterprises -recommendations and good practices" (pristup 03.11.2014), [dostupno na http://ec.europa.eu/enterprise/policies/sme/files/craft/ accounting/doc/accounting_systems_report_en.pdf]

[7] European Commission (2009 ): "Proposal for a Directive of the European Parliament and of the Council amending Council Directive 78/660/EEC on the annual accounts of certain types of companies as regards micro-entities -Impact Assessment - Brussels, 26.2.2009 SEC(2009)
[8] European Commission (2011): Study on Accounting requirements for SMEs - Final Report", (pristup 03.11.2014), [dostupno na http://ec.europa.eu/enterprise/policies/sme/ business-environment/files/study_on_accounting_requirements_for_smes_final_report_en.pdf]

[9] European Commission (2014):"Annual Report on European SMEs 2013/2014 - A Partial and Fragile Recovery" Contract No. 345/PP/ENT/CIP/13/F/N02C031, (pristup 09.11.2014), [dostupno na http://ec.europa.eu/enterprise/policies/sme/ facts-figures-analysis/performance-review/files/supportingdocuments/2014/annual-report-smes-2014_en.pdf]

[10] European Commission (2011): "Proposal for a Directive of the European Parliament and the Councilon the annual financial statements, consolidated financial statements and related reportsof certain types of undertakings - Impact Assessment, SEC(2011) 1290 final, Brussels.

[11] IASC Foundation (2009): IFRS for Small and Medium Sized Entities, www.ifrs.org

[12] International Monetary Fund (2007): "Implementation of IFRS for SMEs in Emerging Economies”, Taxation of Small and Medium Enterprises. Buenos Aires: International Tax Dialogue.

[13] Jermakowicz, E.K. and Epstein, B.J., "IFRS for SMEs-An Option for US Private Entities?” Review of Business Spring, vol. 30, no. 2, pp. 72-79.

[14] Kimmel, P. D., Weygandt, J. J. and Kieso, D. E., Principles of Accounting, Tools for Business Decision Making, USA, Wiley International Edition, 2005, pp. 1-135.

[15] Laptes R. and Popa, A. F. "The Advantages and the Limits of Implementing the Simplified accounting System in Romania", Annals of the Alexandru Ioan Cuza University - Economics, vol. 59, no. 1, pp. 67-78, ISSN (Online) 20688717, DOI: $10.2478 / \mathrm{v} 10316-012-0004-y$

[16] Novak, A., Vrednotenje gospodarskih kategorij pri zunanjem računovodskem poročanju, Koper, Fakulteta za management Koper, 2007, pp. 5-498.

[17] Roberts, C. and Sian, S. (2006): » Micro-entity financial reporting: perspectives of preparers and users«, Information paper prepared for the Small and Medium Practices Committee (New York, USA: IFAC).

[18] Slovenian Accounting Standards (SAS), Ur. l. RS, št. 118/2005; 27. 12. 2005.

[19] Turk, I., Melavec, D. and Korošec, B., Uvod v računovodstvo, Slovenia, Slovenski inštitut za računovodstvo, 2004, pp. $1-235$

[20] Weetman, P., Financial Accounting, Great Britain, Prentice Hall, 2003, pp. 3-444.

[21] Zakon o računovodstvu, Službeni glasnik RS, br. 62/2013

\section{POREĐENJE RAČUNOVODSTVENIH SISTEMA ZA MIKRO PRAVNA LICA U SLOVENIJI I SRBIJI U ODNOSU NA NOVE RAČUNOVODSTVENE DIREKTIVE EU}

Tatjana Jovanović

Faculty of Administration, University of Ljubljana, Gosarjeva ulica 5, Ljubljana, Slovenia, tatjana.jovanovic@fu.uni-lj.si

\begin{abstract}
Apstrakt:
Finansijsko računovodstvo je tradicionalno orijentisano ka istorijskom prikazivanju nastalih poslovnih događaja i pripremi finansijskih izveštaja. Informativna vrednost računovodstvenih izveštaja namenjena je velikom broju korisnika, od vlasnika, finansijera, zaposlenih itd. Dosadašnje iskustvo ukazuje na izdašnu upotrebu informacija iz finansijskih izveštaja u domenu poslovanja malih i srednjih preduzeća (MSP) i preduzetnika, kao i usvajanje računovodstvenih politika koje su ključne za planirane, poslovnu strategiju i taktiku, upravljanje kapitalom, itd. S obzirom na to da MSP (naročito mikro pravna lica) predstavljaju najveći i najefikasniji segment privrede, ovaj rad bavi se pravnim regulativama u oblasti računovodstva i finansijskog izveštavanja za potrebe mikro pravnih lica u Sloveniji i Srbiji i komparativnom analizom sličnosti i razlika između regulatornih okvira i sadržaja regulative, sa posebnim osvrtom na kompleksnost finansijskog izveštavanja na godišnjem nivou u odnosu na nove računovodstvene direktive EU ( 2013/34/EU).
\end{abstract}

\section{Ključne reči:}

računovodstveni sistem, računovodtsvo,

MSP,

mikro pravna lica,

finansijski izveštaj. 